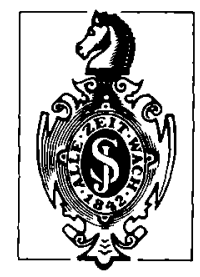



H. Kuckuck • G. Kobabe · G. Wenzel

\section{Fundamentals of Plant Breeding}

With the cooperation of

D. Böringer - W. Hondelmann - V. Stoy - T. Tatlioglu

With 65 Figures

Springer-Verlag

Berlin Heidelberg New York London Paris

Tokyo Hong Kong Barcelona Budapest 
Professor Dr. Dr. h.c. Hermann Kuckuck

Reihermoorweg 5

W-3006 Burgwedel 4, FRG

Professor Dr. GeRD Kobabe

Professor Dr. GeRHARD WeNZEL

Universităt Gơttingen

Institut für Pflanzenbau

Institut für Resistenzgenetik

und Pflanzenzüchtung

Biologische Bundesanstalt für

von-Siebold-Straße 8

W-3400 Gơttingen, FRG

Land- und Forstwirtschaft

W-8059 Bockhorn, FRG

\title{
Contributors:
}

Dr. D. BORINGER

Presidente of the Federal Plant

Professor Dr. W. HondelmanN

Schwetzingenstraße 14

Varieties Office, Germany

Osterfelddamm 80

W-3300 Braunschweig, FRG

W-3000 Hannover 61, FRG

Priv. Doz. Dr. V. StoY

Svalof AB

S-26800 Svalov, Sweden

Professor Dr. T. TATliogw

Institut für Angewandte Genetik

Herrenhäuser Straße 2

W-3000 Hannover 21, FRG

Cover illustration: Combination breeding by application of the bulk population method (s. Fig. 10, page 29).

Title of the original German edition:

Hermann Kuckuck/Gerd Kobabe/Gerhard Wenzel

Grundzüge der Pflanzenzilchtung, 5. Auflage

(C) Verlag Walter de Gruyter \& Co., Berlin 1985

\section{ISBN 3-540-52109-7 Springer-Verlag Berlin Heidelberg New York ISBN 0-387-52109-7 Springer-Verlag New York Berlin Heidelberg}

\begin{abstract}
Library of Congress Cataloging-in-Publication Data. Kuckuck, Hermann, 1903 - [Grundzlige der Pflanzenzuchtung. English] Fundamentals of plant breeding / H. Kuckuck, G. Kobabe, G. Wenzel; with the scientific cooperation of D. Böringer ... [et al.] p. cm. Translation of: Grundzúge der Pflanzenzuchtung. Includes bibliographical references and index. ISBN 0-387-52109-7 1. Plant breeding. I. Kobabe, Gerd. II. Wenzel, Gerhard. III. Title. SB123.K813 1991 631.5'3-dc 20. 91-7971

This work is subject to copyright. All rights are reserved, whether the whole or part of the material is concerned, specifically the rights of translation, reprinting, re-use of illustrations, recitation, broadcasting, reproduction on microfilms or in other ways, and storage in data banks. Duplication of this publication or parts thereof is only permitted under the provisions of the German Copyright Law of September 9, 1965, in its current version, and a copyright fee must always be paid. Violations fall under the prosecution act of the German Copyright Law.
\end{abstract}

(C) Springer-Verlag Berlin Heidelberg 1991

Printed in Germany

The use of registered names, trademarks, etc. in this publication does not imply, even in the absence of a specific statement, that such names are exempt from the relevant protective laws and regulations and therefore free for general use.

Typesetting: International Typesetters Inc., Makati, Philippines 31/3145-543210 - Printed on acid-free paper 